\title{
How far have we come: 75 years 'in clover'?
}

\author{
A.J.PARSONS ${ }^{1}$, G.R.EDWARDS ${ }^{2}$, D.F. CHAPMAN ${ }^{3}$ and R.A.CARRAN ${ }^{1}$ \\ ${ }^{1}$ AgResearch Grasslands, PB 11008, Palmerston North \\ ${ }^{2}$ Agriculture and Life Sciences Division, PO Box 84, Lincoln University, Canterbury \\ ${ }^{3}$ School of Agriculture and Food Systems, University of Melbourne, Victoria 3010, Australia
}

\begin{abstract}
We reflect on what has been a recurring theme in the history of agricultural research in NZ - the understanding that while we grow white clover for its capacity to fix nitrogen, this increase in fertility ultimately passes to benefit the accompanying grass. The association of clover and grass is regarded both as a wonderful harmony upon which our economy depends, but also as a competition between species that too often defeats our efforts to realise clover's full potential. We review and revisit the nature of the interaction between the species, and we offer some radical approaches looking forward. These include simple pragmatic options for management for immediate gains in performance, and we identify the need for some critical rethinking to fundamentally alter how grass and clover interact.
\end{abstract}

Keywords: grass, clover, cycles, patch dynamics, competition

\section{Introduction}

There are few papers, grant proposals, and sector strategies, for NZ agricultural development that do not start with a list of the multiple benefits of white clover (in diet, $\mathrm{N}$ fixation and alleged low environmental impact) only to be followed by a concern that clover is only some $10-20 \%$ of our pastures and this is inadequate. These statements appeared in seminal publications some 50 years ago (after 25 years of NZGA) (e.g. Sears 1962), they appear 10 years ago (e.g. Chapman et al. 1996), and still appear today (Chapman et al. 2006). How far then have we come? Are there new prospects for the future? Other papers in this edition, notably Brock (2006), advise how we can come closer to realising the potential of existing cultivars and management practices. But here we focus on what are the prospects for increasing that potential.

For certain, yields from grass/clover based pastures have increased substantially. Even by 1962 gains in those regions where white clover is viable, had been "manyfold" (comparing P-supplied and 'improved' eg Huia, pastures, to non P-supplied/low clover ones) (Sears 1962). Direct evaluation in 1993 suggested an $80 \%$ increase attributable to $\mathrm{P}$, and a $12 \%$ increase attributable to clover improvement (Tahora vs unimproved hill country species) (Chapman et al. 1993). So the amount of both clover and grass has increased, but the proportion of clover has remained small. Why has it been so difficult to increase clover content?

\section{A History of Cycles and Cycles of History}

A full 50 years ago, there was a clear understanding of the problems involved in improving performance from the two-species, grass/clover, interaction. Sears (1962) made very clear the problem was that any stimulation of clover (e.g. by $\mathrm{P}$ input) would lead to an increase in $\mathrm{N}$ fixed by clover, stimulating in turn the growth of the other plant species, the grass. This was after all both the purpose, and the pitfall, of the nature of this particular plant species association. The analyses made clear that total yields could increase but that an increase in proportion of clover was unlikely to be sustainable. At that time, it was unclear whether the system would move inexorably to some sustained (presumed deleterious) high $\mathrm{N}$, low clover state. And there was talk (Sears 1962) of the need to 'reset the biological clock', e.g. using cropping to run down soil $\mathrm{N}$ so clover could predominate again in any pasture resown.

Ten years ago, with the benefit now of computer modelling, and collating much detailed work on the mechanisms and dynamics of $\mathrm{N}$ fixation, growth, grazing and $\mathrm{N}$ cycling, the whole concept was revisited, (Schwinning \& Parsons 1996a,b). What Sears (1962) saw as a problem of long-term succession following increased $\mathrm{P}$ use at a landscape or whole farm scale, these authors saw as operating also on a short time scale (2-4 years), in patches within a paddock, perturbed by grazing and sporadic $\mathrm{N}$ inputs via urine. Working at the scale of patches/paddocks, Schwinning \& Parsons (1996c) proposed the 'biological clock' resets itself automatically, every c. 4 years. A simplified summary of the theory is available in Parsons and Chapman (2000).

Schwinning and Parsons (1996a) recognised that 'exploitation' interactions (e.g. as the $\mathrm{N}$ fixed by clover is exploited by the grass), can exhibit behaviour like a 'predator-prey' system (see Fig. 1). Like the well known and more intuitive examples of lynx (predator) and hares (prey), these systems are prone to wide population cycles. They benefit from showing 'self regulation', but as a consequence are notoriously difficult to manipulate. In the grass/clover context this explains why any boost to the 'prey/clover' leads ultimately to a boost instead to the 'predator/grass', this being the 'paradox of enrichment' 
Figure 1 Zero net growth isoclines for grass and clover show the combinations of grass mass and clover mass in a selectively grazed mixture that lead to no change in grass mass (solid line) or no change in clover mass (dashed line). The point of intersection of these is therefore the combinations of grass and clover that can be sustained (at equilibrium) in the mixture. (a) Populations of grass and clover may cycle around this equilibrium showing damped oscillations but (b) the cycles may be more marked and sustained by the repeated random deposition of urine. (Schwinning \& Parsons 1996a). In (c) a spatial pasture model predicts the spontaneous formation of legume patches. White: legume dominant areas; light grey: grass dominant grass/clover areas (high soil N); dark grey: grass only areas (high soil N); black: grass only areas (low soil N). (Schwinning \& Parsons 1996b; reproduced from Parsons \& Chapman 2000).
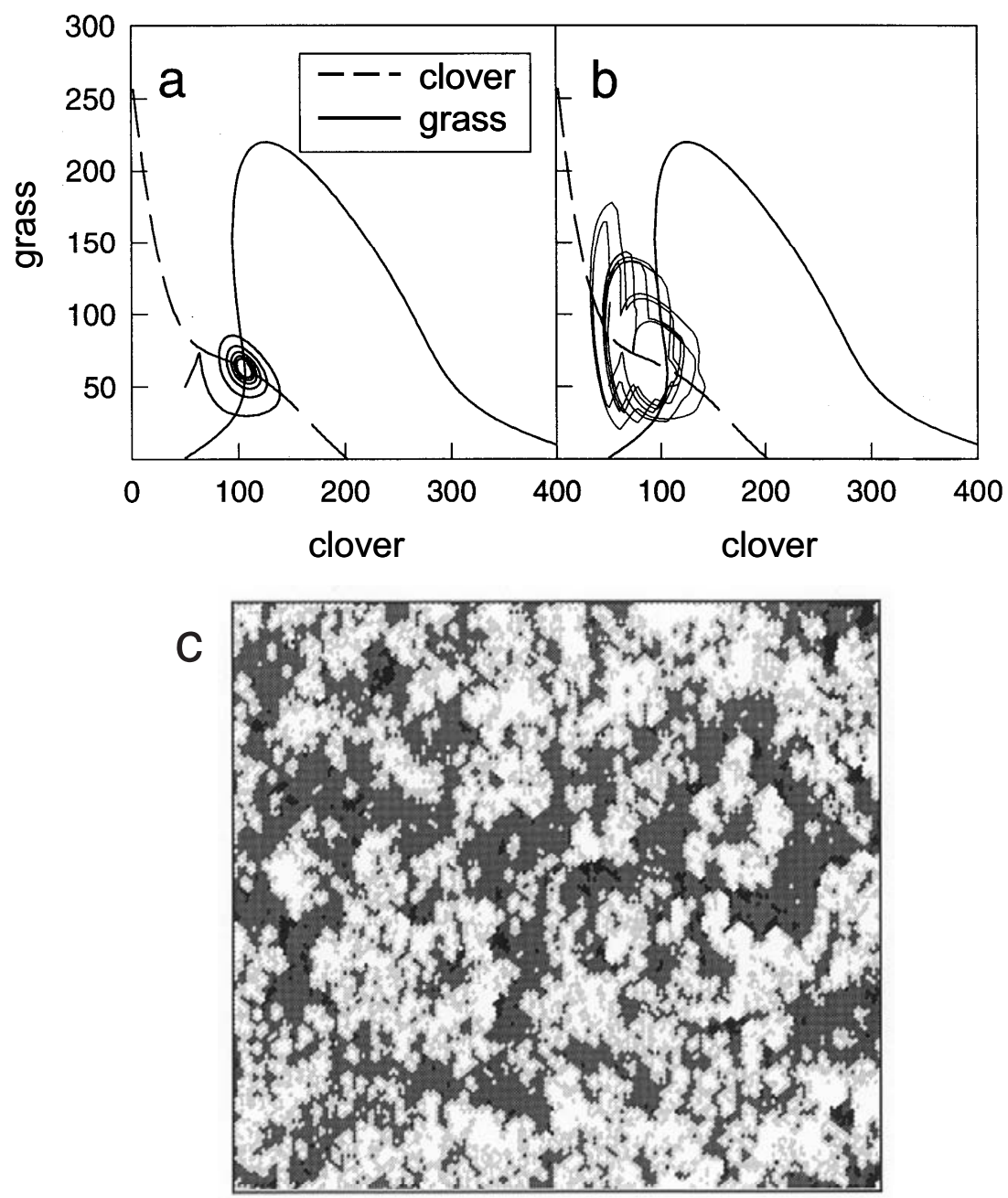

(Rosenzweig 1977). To improve the system would demand working on the performance and fate of both species simultaneously (and not trying to improve clover separately from grass).

This approach offered explanations for five major observations: i) how clover was able to co-exist with grass at all! ii) why the proportion of clover remains low, iii) why clover is present 'only' in patches, iv) why the patches 'move around', and v) why there is great uncertainty and variation (perceived as risk) in clover proportions and amount, with declines in clover content after sowing, and so called 'good' and 'bad' clover years. In effect the system seeks a balance, a soil $\mathrm{N}$ concentration, at which clover's advantage (in being capable of $\mathrm{N}$ fixation) is exactly countered by grass's competitive advantage when at higher mineral N. Such a solution, in a complicated dynamic interaction, we call an 'attractor'. Like a drain hole in a dairy shed floor, everything is drawn toward it, but can overshoot and cycle around it.

To make progress, we re-visited over the last 10 years what have been proposed as the two major forces that 
challenge clover 'persistence', namely 'competition' with grass, and preference for clover by animals. By simply growing grass and clover separately we removed nearly all problems in sustaining the sown proportions of clover (e.g. 50-70\% by ground area easily sustained) (Parsons et al. 1994). This strongly suggests that plant to plant species 'interaction' (exploitation/competition) is indeed the dominant force in limiting clover content (though when the species are grown together these two forces compound). Likewise, growing the species separately confirmed that, although there was a strong preference by ruminants for clover (preferred diet some $70 \%$ clover) (Parsons et al. 1994), the ensuing changes in the availability (height and mass) of the clover monoculture area alter what animals are able to select and clover is not grazed to extinction (Rook et al. 2002)

\section{Looking Forward - Trials of Separation?}

Looking to the future with these insights we can suggest, with some confidence, what it would take to improve grass/clover further.

First, pragmatically is, 'why not just routinely grow grasses and clover separately?' This could be separate in space (animals grazing adjacent monocultures in the same paddock) or separate in time (animals offered grass or clover monocultures at different times of day (e.g. post milking) or in the season (peak lactation, or finishing).

Analysis of animal behaviour revealed unexpected possibilities as there was evidence of a boost to grazing time (total minutes grazing per day relative to pure clover) when animals were offered a food choice (Champion et al. 1998, 2004; Cosgrove et al. 2001). The exhaustive studies of animal and plant responses at IGER (see Penning et al. 1995; Edwards et al. 1995; Newman et al. 1995) offered sufficient promise to justify following up with expensive animal production trials. Nuthall et al. (2000) showed a substantial and significant boost to milk yield (an extra 2-3 kg per day) from cows offered adjacent monocultures compared to mixed swards, over the first 6 weeks of lactation. An array of subsequent studies (Table 1) show per-animal performance from spatially separated monocultures of ryegrass and white clover to be generally higher than that from conventional mixtures, and similar to a pure white clover monoculture. The improved performance over the mixtures is mainly due to animals being able to sustain a higher proportion of white clover in the diet, although increased daily intake (from increased total grazing time) under spatial separation has contributed in two cases (Champion et al. 1998; Cosgrove et al. 2001). These gains (c. 10\% in milk; $25+\%$ in liveweight gain, Table 1) would compare favourably with the $c .1 \%$ per year gain in DM production of the clover component from plant breeding.

Growing grass and clover separately also presents appealing opportunities for targeting management inputs to the needs of individual pasture components without compromising the performance of associated species. Fertilisers and weed control can be targeted to each species separately. Grazing pressure can be monitored to prevent over/under grazing of each species (and adjusted by land allocation). Because clover and grass cultivars are often bred separately, improved cultivars might even express their improvements better if they were grown separately too. Indeed, spatial separation may be a sensible test

Table 1 Milk yield (kg/head/day), liveweight (LWT) change (g/head/day) and wool growth ( $\mathrm{g} / \mathrm{head} / \mathrm{day}$ ) measured on different pasture types. $\mathrm{G}=$ ryegrass monoculture; $\mathrm{C}=$ clover monoculture; Choice = adjacent monoculture of grass and clover in 50:50 area ratio; Mix = intermingled grass/clover mixture. (From: Chapman et al. 2006).

\begin{tabular}{|c|c|c|c|c|c|c|c|c|}
\hline \multirow{2}{*}{ Reference } & \multirow{2}{*}{ Animal type } & \multirow{2}{*}{$\begin{array}{l}\text { Variable } \\
\text { measured }\end{array}$} & \multirow{2}{*}{ Days } & \multicolumn{4}{|c|}{ Pasture treatment } & \multirow{2}{*}{$\mathrm{P}$} \\
\hline & & & & $\mathrm{G}$ & $\mathrm{C}$ & Choice & Mix & \\
\hline Rutter et al. 2003 & Dairy cows & Milk yield & 28 & $\mathrm{~nm}$ & $\mathrm{~nm}$ & $31.4 \mathrm{a}$ & $27.4 \mathrm{~b}$ & $<0.05$ \\
\hline Marotti (2004) & Dairy cows & Milk yield & 6 & $18.6 \mathrm{a}$ & $24.2 \mathrm{c}$ & $23.2 \mathrm{c}$ & $21.3 b$ & $<0.001$ \\
\hline \multirow{4}{*}{$\begin{array}{c}\text { Cosgrove et al. } 2003 \\
" \\
" \\
"\end{array}$} & Ewes & LWT change & 31 & -100 & 50 & 75 & $\mathrm{~nm}$ & NS \\
\hline & Suckling lambs & LWT change & 31 & 245 & 315 & 320 & $\mathrm{~nm}$ & NS \\
\hline & Weaned lambs & LWT change & 30 & $185 \mathrm{a}$ & $345 \mathrm{~b}$ & $330 \mathrm{~b}$ & $205 a$ & $<0.01$ \\
\hline & Hoggets & LWT change & 35 & $190 \mathrm{a}$ & $275 b$ & $245 b$ & $\mathrm{~nm}$ & $<0.05$ \\
\hline Venning et al. 2003 & Ewes & LWT change & 49 & $84 \mathrm{a}$ & $271 b$ & $225 b$ & $145 \mathrm{a}$ & $<0.001$ \\
\hline$"$ & Suckling lambs & LWT change & 49 & $260 \mathrm{a}$ & $381 \mathrm{c}$ & $382 \mathrm{c}$ & $303 b$ & $<0.001$ \\
\hline Venning et al. 2004 & Ewes & LWT change & 98 & $81 \mathrm{a}$ & $131 \mathrm{~b}$ & $171 \mathrm{c}$ & $86 \mathrm{a}$ & $<0.001$ \\
\hline$"$ & Suckling lambs & LWT change & 84 & $246 a$ & $309 \mathrm{~b}$ & $329 \mathrm{~b}$ & 269 a & $<0.001$ \\
\hline$"$ & Ewes & Wool growth & 98 & $11.2 \mathrm{a}$ & $12.8 \mathrm{~b}$ & $13.8 b$ & $12.2 \mathrm{ab}$ & $<0.05$ \\
\hline Champion et al. 2004 & Suckling lambs & LWT change & 10 & $17.2 \mathrm{~b}$ & $26.4 \mathrm{c}$ & $19.8 b$ & $14.3 \mathrm{a}$ & $<0.05$ \\
\hline $\begin{array}{l}\text { Edwards G.R. } \\
\text { (unpublished) }\end{array}$ & Suckling lambs & LWT change & 60 & & $\mathrm{~nm}$ & $330 b$ & $280 a$ & $<0.01$ \\
\hline
\end{tabular}


Figure 2 Mean seasonal distribution of clover growth relative to grass (\% clover in standing biomass of mixture) from 1960 to 1985 at Winchmore under various irrigation treatments: Solid symbols, solid line $20 \%$; broken line $15 \%$; dotted line $10 \%$ of field capacity and open circles, dotted line - no irrigation. From Rickard \& McBride (1986).

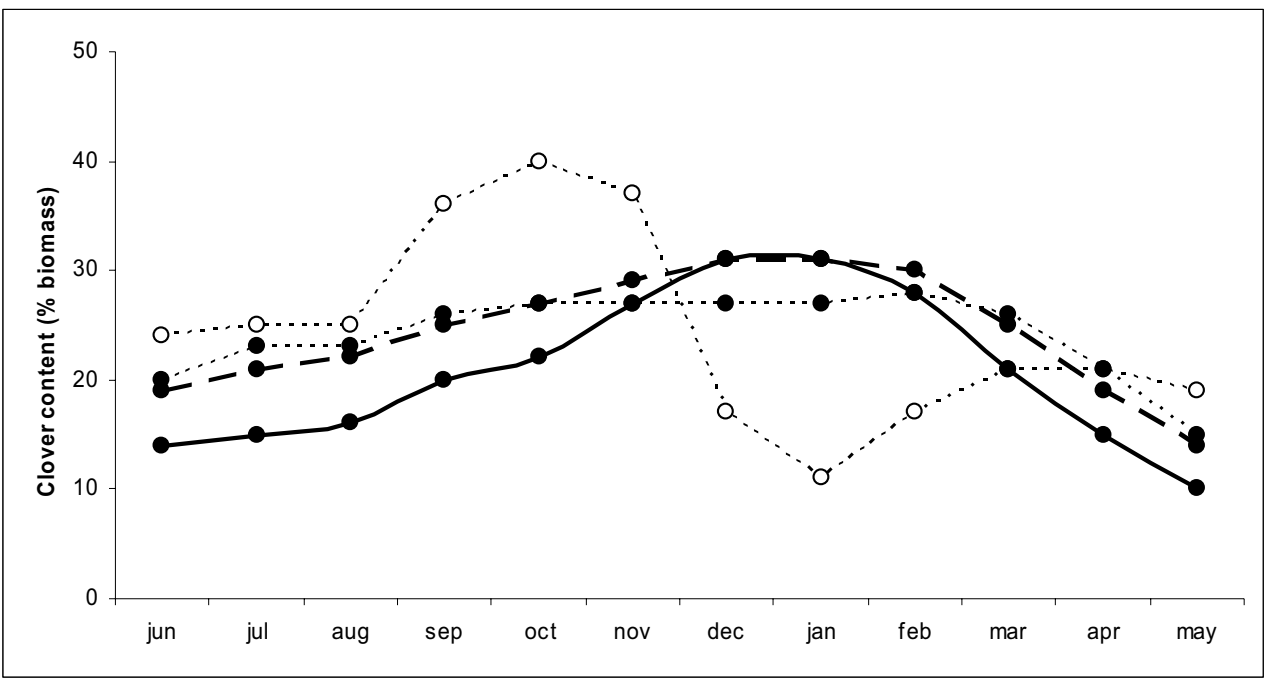

method of incorporating new plant material with novel nutritional characteristics, but weak competitive performance, into systems to ensure the sustainable delivery of nutrients to grazing animals.

Despite this success, there remain concerns over adopting this approach. Analysing these is revealing. One perceived drawback is lower per-hectare production associated with clover monocultures due to their $25 \%$ lower total annual production compared to well fertilised grass (Harris \& Hoglund 1977). Two further concerns with spatial separation are pest attack (notably nematodes or clover root weevil); and potential $\mathrm{N}$ leaching losses from clover during cool winter months (as $\mathrm{N}$ leaching losses from clover monocultures can be similar to heavily $\mathrm{N}$ fertilised perennial rygegrass, MacDuff et al. 1991). This list is long enough to be damning, until it is recognised that these are not draw-backs of growing legumes separate from grass per se, but of having a large proportion of clover in the system, by whatever means! While clover fixes nitrogen, total (grass + clover) yields may increase even if the clover itself is less productive than grass, but there will clearly be a limit. Cosgrove (2005) used a simple simulation model to show that for a dairy farm, milk solids/ha should increase up to a point where $60 \%$ of the farm was white clover (see also Clark \& Harris 1996). On pest damage, we need to establish if this is actually worse (for a given clover abundance), if that is made up of a single large patch, or of say 10 typical clover-dominant patches, and how best to target pest control, before weighing up different approaches to increasing clover content. Growing clover monocultures would be a particularly valuable tool in pest control studies to separate the role of pests in fluctuations in clover yield distinctly from issues of clovers' interaction with grass.

\section{Looking Forward - Shifting Attraction?}

The second route to improving grass/clover systems sounds more conventional, but may require even greater challenges to conventional thinking. Growing the species conventionally in mixtures, and relying on plant improvements, sounds intuitive but requires modifying the very nature of the interaction between the two species. It is perhaps of value to critically reconsider just what aspects of clover growth, grass growth and their combined fate need attention.

First, we could alter one of the forces that shape 'competition' when the species are mixed, by persuading animals to show less preference for clover. This would not be achieved by anti-feedants but by distributing whatever the animals seek and prefer in clover more evenly between it and grass. Ruminants are astonishingly able to associate even abstract cues with feeding value and these behavioural associations are very flexible (Edwards et al. 1996, 1997).

Next, we could work through a conventional list of clover improvements. But these too may need revisiting. It is widely stated that white clover competes poorly with grass, though grows well in warm conditions in summer/autumn, but a glance at historic data (e.g. Fig. 2 - Winchmore 1960-1985 (Rickard \& McBride 1986)), shows that, each and nearly every year, the clover proportion increases (so clover is growing faster than grass!) throughout the first half of the season, at a time 
Table 2 Predicted effects of manipulating some physiological attributes of white clover, based on a model of grass/clover dynamics acting via N cycling (Schwinning \& Parsons 1996a,b). From Chapman et al. (1996). Units: grams Carbon or Nitrogen per $\mathrm{m}^{2}$ ground area per day and (in brackets) yields relative to default run of model $=100$.

\begin{tabular}{|c|c|c|c|c|c|}
\hline \multirow{2}{*}{ Model scenario } & \multirow{2}{*}{$\begin{array}{l}\text { Pasture yield } \\
\left(\mathrm{g} \mathrm{C}^{2} / \mathrm{m}^{2} / \mathrm{d}\right)\end{array}$} & \multirow{2}{*}{$\begin{array}{c}\text { Clover } \\
\%\end{array}$} & \multicolumn{2}{|c|}{ Total biomass $\left({\left.\mathrm{g} \mathrm{C} / \mathrm{m}^{2}\right)}^{2}\right.$} & \multirow{2}{*}{$\begin{array}{l}\text { N losses } \\
\left(\mathrm{g} \mathrm{N} / \mathrm{m}^{2} / \mathrm{d}\right)\end{array}$} \\
\hline & & & Clover & Grass & \\
\hline Default & $0.96(100)$ & 51 & 132 & 126 & 0.223 \\
\hline Increasing competitive ability of clover & $1.14(118)$ & 51 & 161 & 156 & 0.265 \\
\hline Increasing efficiency of $\mathrm{N}$ fixation & $1.18(122)$ & 46 & 126 & 145 & 0.273 \\
\hline Decreasing retention of $\mathrm{N}$ fixation & $1.03(107)$ & 64 & 154 & 85 & 0.238 \\
\hline
\end{tabular}

when grass growth rate is known to be maximum. This is totally contrary also to the notion that clover is vulnerable in spring, because of the fragmentation (topology and burial) of stolons. At these rates clover would take over the pasture in very few years. Its problems lie clearly in late summer/autumn (when grass growth has slowed), and so it is forced to restart each year from a poor position. The Winchmore data suggest this problem is not totally avoided by irrigation.

But the bottom line is we would have to move the 'attractor'. If what Sears (1962), long ago, and Schwinning et al. (1996a) propose is the case, then we must alter the amount of clover it takes to achieve that soil $\mathrm{N}$ that balances the species' competitive abilities. This would require altering the way in which clover shuts down fixation as soil mineral $\mathrm{N}$ rises, and the clover itself 'trades off' $\mathrm{N}$ fixation in favour of its own uptake of mineral $\mathrm{N}$.

Improvements in one component (e.g. the clover) alone will not achieve the simple intuitive benefit of increasing clover, if grass and clover interact in the way that we have argued. Recent reviews acknowledge this interaction but conclude that, because grass and clover interact and notably via nitrogen (below ground), we need more aggressive root systems (and fewer root pests) to increase clover's competition for N. If our 'model' of the interaction is valid, however, the results could be counterintuitive. In Table 2 we illustrate (with the same model) how increasing above ground competitive ability of clover might lead to greater grass and clover yields, with little or no change in percent clover content. Increasing $\mathrm{N}$ fixation efficiency also increased yields, but decreased clover content. Persuading clover to shut down $\mathrm{N}$ fixation to a greater extent as mineral $\mathrm{N}$ rises (reducing the extra costs of $\mathrm{N}$ fixation and switching to more efficient $\mathrm{N}$ uptake) gave the greatest increase in clover content, though in this example a smaller increase in yield. Changes in the balance of fixation and uptake of $\mathrm{N}$ by clover may also affect the cycling of grass/clover dominance and so patchiness and the cycle of 'good' and 'bad' years. There is wide variation in this trait and germplasm has been selected for such a purpose in NZ (Crush \& Caradus 2001) but a new (funding) impetus is needed to pursue these prospects.

\section{Critical reflection and radical thinking needed to keep us 'in clover'}

Lastly, we must be realistic about our past successes and future expectations from plant breeding. One of the more recent clover cultivars to be released by AgResearch and its partners is the award winning 'Crusader' ('Apex' in NZ). Growing in a mixture with ryegrass, yields of this clover were $29 \%$ more than that of the 1957 cultivar Huia growing in the same trials (Woodfield et al. 2001). This equates to an average yield gain of the clover component of $<1 \%$ per annum. It is very important to note, however, that there is a critical need for more published evidence that these gains in clover yield are associated with gains in yields of the mixture, or more so in animal performance. Given our commitment to progress through plant breeding, there have been surprisingly few trials published to document animal performance gains arising directly from this. In one such rare trial, animal gains from plant improvements were assessed by comparing milk yield (in farmlets) from all combinations of new (1990s) and old (1980s) grass and clover. There was a significant increase in milk yields in only 1 out of 4 years. The authors (Crush et al. 2006) argue the system was close to the "practical limit achievable" in that region. Our point here is that some radical rethinking may be needed if we have realistic expectations of upping the performance of grass/legume based pastures in the next decade to the extent our industry strategies ask.

It is perhaps as well there are simple practical options, such as growing the species separately, to boost total milk yield and delay the decline in mid-lactation. Shifting an attractor is a tougher option, but we will not make progress unless the complexity of improving a system of interacting species is more widely recognised - not just as a 50 year legacy, but as a fundamental challenge that we now have unprecedented opportunity to overcome. 


\section{ACKNOWLEDGEMENTS}

The study of grass/legume interaction by Schwinning \& Parsons (1996a,b,c) was funded by the Biotechnology and Biological Sciences Research Council (UK) at the Institute for Grassland and Environmental Research, Devon, and its presentation in NZ by an AgResearch Senior Research Fellowship in 1995/6 at Grasslands, Palmerston North. We extend our thanks also the Universities of Melbourne (Victoria); Lincoln (NZ); and Imperial College (UK).

\section{REFERENCES}

Brock, J.L. 2006. Grazing management of white clover in mixed pastures. Proceedings of the New Zealand Grassland Association 68: XXXX.

Champion, R.A.; Rutter, S.M.; Orr, R.J.; Penning, P.D. 1998. Costs of locomotive and ingestive behaviour by sheep grazing grass or clover monocultures or mixtures of the two species. p213 In: Proceedings of the 32nd Congress of the International Society for Applied Ethology, Clermont Ferrand, (France), July 1998.

Champion, R.A.; Orr, R.J.; Penning, P.D.; Rutter, S.M. 2004. The effect of spatial scale of heterogeneity of two herbage species on the grazing behaviour of lactating sheep. Applied Animal Behavioural Science 88: 61-76.

Chapman, D.F.; Mackay, A.D.; Devantier, B.P.; Dymock, N. 1993. Impact of white clover cultivars on nitrogen fixation and livestock production in a New Zealand hill pasture. Proceedings of the International Grassland Congress 17: 420-421.

Chapman, D.F.; Parsons, A.J.; Cosgrove, G.P.; Barker, D.J.; Marotti, D.M.; Venning, K.; Rutter, S.M.; Thompson, A.N. 2006. Impacts of spatial patterns in pasture on animal grazing behaviour, intake and performance. Crop Science: in press.

Chapman, D.F.; Parsons, A.J.; Schwinning, S. 1996. Management of clover in grazed pastures: expectations, limitations and opportunities. White Clover: New Zealand's Competitive Edge. Grassland Research and Practice Series 6: 55-64.

Clark, D.A.; Harris, S.L. 1986. White clover or nitrogen for dairying? White Clover: New Zealand's Competitive Edge. Grassland Research and Practice Series 6: 107-114.

Cosgrove, G.P. 2005. Novel grazing management: making better use of white clover. pp 181-190 In: Proceedings of South Island Dairy Event, Lincoln University, 20-22 June 2005.

Cosgrove, G.P.; Parsons, A.J.; Marotti, D.M.; Rutter, S.M.; Chapman, D.F. 2001. Opportunities for enhancing the delivery of novel forage attributes. Proceedings of the New Zealand Society for Animal Production 61: 16-19.
Cosgrove, G.P.; Hyslop, M.G.; Anderson, C.B.; Litherland, A.J.; Lambert, M.G. 2003. Integrating novel forage management into sheep farm systems. Proceedings of the New Zealand Grassland Association 65: 75-81.

Crush, J.R.; Caradus, J.R. 2001. Selection for variation in residual nitrogenase activity after exposure of white clover (Trifolium repens) to mineral nitrogen. New Zealand Journal of Agricultural Research 44: 135140.

Crush, J.R.; Woodward, S.L.; Eerens, J.P.J.; MacDonald, K.A. 2006. Growth and milksolids production in pastures of older and more recent ryegrass and white clover cultivars under dairy grazing. New Zealand Journal of Agricultural Research 49: 119-135.

Edwards, G.R.; Parsons, A.J.; Penning, P.D.; Newman J.A. 1995. Relationship between vegetation state and bite dimensions of sheep grazing contrasting plant species, and its implications for intake rate and diet selection. Grass and Forage Science 50: 378-388.

Edwards, G.R.; Newman, J.A.; Parsons, A.J.; Krebs, J.R. 1996. The use of spatial memory by grazing animals to locate food patches in spatially heterogeneous environments: an example with sheep. Applied Animal Behaviour Science 50: 147- 160.

Edwards, G.R.; Newman J.A.; Parsons, A.J.; Krebs, J.R. 1997. Use of cues by grazing animals to locate food patches: an example with sheep. Applied Animal Behaviour Science 51: 59-68.

Harris, W.; Hoglund, J.H. 1977. Influences of seasonal growth periodicity and $\mathrm{N}$-fixation on competitive combining abilities of grasses and legumes. pp 239243 In: Proceedings of the XIII International Grassland Congress.

MacDuff, J.H.; Jarvis, S.C.; Roberts, D.H. 2001. Nitrates: leaching from grazed grassland systems, pp. 405-410 In: Nitrates, agriculture, Ed. R. Calvet, eau. INRA, Paris.

Marotti, D.M. 2004. Behavioural Limitations to Pasture Intake of Ruminants. PhD thesis, University of Melbourne.

Marotti D.M.; Cosgrove G.P.; Chapman D.F.; Parsons, A.J.; Egan A.R.; Anderson C.B. 2001. Novel methods of forage presentation to boost nutrition and performance of grazing dairy cows. Australian Journal of Dairy Technology 56: 161.

Newman, J.A.; Parsons, A.J.; Thornley, J.H.M.; Penning, P.D.; Krebs, J.R. 1995. Optimal diet selection by a generalist grazing herbivore. Functional Ecology 9: 255-268.

Nuthall, R.; Rutter, S.M.; Rook, A.J. 2000. Milk production by dairy cows grazing mixed swards or adjacent monocultures of grass and white clover. Pp 37-38 In: Sixth Research Conference of the British 
Grassland Society, British Grassland Society.

Parsons, A.J.; Chapman, D.F. 2000. The principles of pasture growth and utilisation. pp. 31-89 In: Grass its production and utilisation. Third Edition. Ed. A. Hopkins. British Grassland Society. Blackwell Scientific Publications.

Parsons, A.J.; Newman, J.A.; Penning, P.D.; Harvey, A.; Orr, R.J. 1994. Diet preference of sheep: effects of recent diet, physiological state and species abundance. Journal of Animal Ecology 63: 465-478.

Penning, P.D.; Parsons, A.J.; Orr, R.J.; Harvey, A.; Champion, R.A. 1995. Intake and behaviour responses by sheep in different physiological states, when grazing monocultures of grass or white clover. Applied Animal Behaviour Science 45: 63-78.

Rickard, D.S.; McBride, S.D. 1986. Irrigated and nonirrigated pasture production at Winchmore, 1960 to 1985. Technical Report No. 21. Ministry of Agriculture and Fisheries.

Rook, A.J.; Harvey, A.; Parsons, A.J.; Renning, P.D.; Orr, R.J. 2002. Effect of long-term changes in relative resource availability on dietary preference of grazing sheep for perennial ryegrass and white clover. Grass and Forage Science 57: 54-60.

Rosenzweig, M.L. 1977. Aspects of biological exploitation. Quarterly Review of Biology 52: 371380.

Rutter, S.M.; Young, K.L.; Cook, J.E.; Champion, R.A. 2003. Strip grazing separate white clover and ryegrass monocultures increases daily intake and milk yield in dairy cows. Tropical and Subtropical Agroecosystems 3: 461-465.
Schwinning, S.; Parsons, A.J. 1996a. Analysis of the coexistence mechanisms for grasses and legumes in grazing systems. Journal of Ecology 84: 799-814.

Schwinning, S.; Parsons, A.J. 1996b. A spatially explicit population model of stoloniferous $\mathrm{N}$-fixing legumes in mixed pasture with grass. Journal of Ecology 84: 815-826.

Schwinning, S.; Parsons, A.J. 1996c. Interaction between grasses and legumes: understanding variability in species composition. Legumes in Sustainable Farming Systems, Proceedings, Sustainable Farming Systems / British Grassland Society Joint Conference, Aberdeen, Sept 1996.

Sears, P.D. 1962. Exploitation of high production pastures in New Zealand. Proceedings of the New Zealand Ecological Society 9: 57-63.

Venning, K.; Thompson, A.; Kennedy, A.; Chapman, D. 2003. Prime lamb production from adjacent monocultures of grass and clover. p. 81-82. In: Proceedings Joint Conference Grassland Societies, Victoria and NSW.

Venning, KJ., Thompson, A.N., Chapman, D.F., Kearney, G. 2004. Ewe and lamb growth from adjacent monocultures of grass and clover. p 336 In: D.K. Revell and D. Taplin (eds.) Animal Production in Australia, Vol. 25. Australian Society Animal Production, Adelaide, Australia.

Woodfield, D.R.; Clifford, P.T.P.; Cousins, G.R.; Ford, J.L.; Baird, I.J.; Miller, S.L.; Woodward, S.L.; Caradus, J.R. 2001. Grasslands Kopu II and Crusader: New generation white clovers. Proceedings of the New Zealand Grassland Association 63: 103-108. 